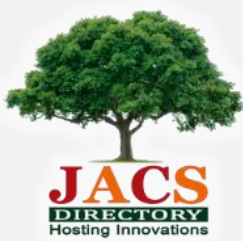

Journal of Nanoscience and Technology

\title{
Silver Nanoparticles: The Powerful Antidote for Bacterial Blight Disease of Pomegranate
}

\author{
A.S. Sherkhane ${ }^{1, *}$, H.H. Suryawanshi ${ }^{1}$, P.S. Mundada ${ }^{2}$, B.P. Shinde ${ }^{1}$ \\ ${ }^{1}$ Dept of Biotechnology, Vidya Pratishthan's Arts, Science and Commerce College, Baramati - 413 133, Maharashtra, India. \\ ${ }^{2}$ Department of Biotechnology, Yashavantrao Chavan Institute of Science, Satara - 415001 , Maharashtra, India.
}

\section{ART ICLE DETAILS}

\section{Article history:}

Received 17 May 2018

Accepted 30 June 2018

Available online 07 July 2018

\section{Keywords:}

Bacterial Blight

Xanthomonas axonopodis

Silver Nitrate

\begin{abstract}
A B S T R A C T
Successful cultivation is difficult to pomegranate growers due to Xanthomonas axonopodis pv. punicae which cause bacterial blight disease to pomegranate has become serious threat. However, everyone is looking for solution; this problem is resolved by synthesizing silver nanoparticles by the reduction of silver ions in aqueous solutions with the help of green synthesis method. The causative agent was isolated from the infected pomegranate fruits and was tested with silver nanoparticles which are synthesized from leaf extracts of tulsi and neem; and it was found that silver nanoparticle from tulsi extract with $15 \mathrm{mM}$ concentration showed maximum zone of inhibition $22 \mathrm{~mm}$ and $19 \mathrm{~mm}$ for neem, while at $1 \mathrm{mM}$ concentration shows minimum. This study showed that synthesized silver nanoparticles are powerful weapon to control the growth of Xanthomonas axonopodis pv. punicae.
\end{abstract}

\section{Introduction}

Pomegranate is important fruit crops which are cultivated in arid and semiarid regions of the world; however is gaining lot of attention of total world over due to its high nutritional and economics values [1, 2]. In addition pomegranate is used in several purposes as diarrhea, ulcers [3], diabetes [4], male infertility [5], and antiparasitic agent [6]. In the recent year pomegranate cultivation is creating problem due to bacterial blight disease Xanthomonas axonopodis pv. punicae which shows on leaves, stems as well as on fruits and reduce crop yield up to $60-80 \%$. This disease could not be effectively controlled by antibiotics, chemicals [7-9]. Now a day, nanoscience is rapidly growing field with great application for generating nanoparticles and biosynthesis of silver nanoparticles by using medicinal plants in agriculture due to their diverse effect [10]. Silver nanoparticles have great importance in the field of medical due to its broad spectrum application in the medical field $[11,12]$. The synthesis of nanoparticles by biological method show better results than the chemical methods and is easily scaled up for large scale synthesis and cost effective $[13,14]$. The use of plant extract for the synthesis of nanoparticles is adventitious, because it does not require the processes like intracellular synthesis, purification steps and the maintenance of microbial cell cultures. In the present study the causative agent was isolated from the infected pomegranate fruits and to control of this disease silver nanoparticles were synthesized from leaf extracts of tulsi and neem at variable concentrations $(1 \mathrm{mM}, 5 \mathrm{mM}, 10 \mathrm{mM}$ and $15 \mathrm{mM})$. However, the plant extracts are potentially effective than microorganisms with respect to stabilization by provide capping agents for the silver nanoparticles, prevent the aggregation of nanoparticles and free from toxic chemicals [15]. Antimicrobial activity of silver nanoparticles depends mostly on the relative surface area; even though; the smaller silver nanoparticles can have greater toxic potentials [16, 17]. However, the results were confirmed and characterized by UV-visible spectroscopy and Antimicrobial activity of silver nanoparticles was evaluated against bacterial blight disease Xanthomonas axonopodis pv. punicae for diagnosis, treatment, control and to manage disease which will be beneficial to farmers as well as further studies must be conducted to verify if the bacteria develop resistance towards the nanoparticles or not.

\section{Experimental Methods}

\subsection{Sample Collection of Infected Fruits}

The infected fruits showing the typical symptoms of bacterial spot were collected from farmer's fields of major pomegranate growing areas of Baramati in Pune district. The fruits showing typical symptoms like yellowish brown spots, decolouration, minute water soaked lesions, cankers lesions and irregular yellow and brown patches.

\subsection{Isolation of Disease Causing Bacteria from Infected Fruit Part}

Infected fruits samples are collected from orchard. Ooze test is performed by cutting $1 \mathrm{~cm}$ of the infected portion of the fruit and the outer surface was removed and sterilized with $0.1 \% \mathrm{HgCl}_{2}$ solution for 1 minute and washed 3 times with sterile distilled water. Then the infected portion was squeezed gently with a sterile scalpel to get a suspension in a sterile test tube containing $3 \mathrm{~mL}$ of sterilized saline. The suspension was serially diluted and plated in sterilized petri plates containing YDC Agar medium (yeast extract-10 g/L, dextrose- $20 \mathrm{~g} / \mathrm{L}$, calcium carbonate - $20 \mathrm{~g} / \mathrm{L}$, agar$25 \mathrm{~g} / \mathrm{L}, \mathrm{pH} 6.5$ ). Inoculated plates were incubated at $30^{\circ} \mathrm{C}$ for 72 hours. After the incubation period, light yellow colored bacterial colonies were developed resembling Xanthomonas sp. Further cultures were screened based on biochemical characterization according to Bergey's manual of determinative bacteriology (Fig. 1).

\subsection{Purification of Bacterial Culture}

The suspected bacterial colonies were picked up with the help of sterilized inoculated loop and streaked onto the surface of YDC Agar. The inoculated plates were incubated at $30{ }^{\circ} \mathrm{C}$ for 72 hours and the observations were made for the development of well separated light yellow colored bacterial colonies. The purified bacterial colonies were streaked on nutrient agar slants and stored at $4{ }^{\circ} \mathrm{C}$ in refrigerator and also in sterile distilled water taken in small culture tubes, by suspending 2-3 loops full of the bacterial culture for future use.

\subsection{Identification of Causal Organism}

The morphological characteristics such as cell shape, gram staining (Table 1) and biochemical test (Table 2) was performed for the identification of causative agent of oil spot disease of the isolate.

\subsection{Synthesis of Silver Nanoparticles using Plant Extracts}

Around $5 \mathrm{~g}$ of fresh tulsi, and neem leaves were collected from the biovillage, VSBT of VPASC College, Baramati. All the veins were removed and 
leaves were crushed in deionized water. After crushing the extract was filtered using Whatman filter paper no. 1 . The $2 \mathrm{~mL}$ and $5 \mathrm{~mL}$ of extract filtrate was collected and then added in various concentrations of silver nitrate solution $(1 \mathrm{mM}, 5 \mathrm{mM}, 10 \mathrm{mM}$ and $15 \mathrm{mM})$. This reaction was kept under dark condition for more than a week. Tubes were monitored after every 24 hours and reactions showing precipitation of silver particles were discarded. After 15 days reaction the color of the solution of silver nanoparticles was analyzed by UV visible spectroscopy (Fig. 2). Reaction showing peaks at around $390 \mathrm{~nm}-430 \mathrm{~nm}$ was chosen for further study (Table 3). This solution was centrifuged at 10,000 rpm for 10 minutes, and the precipitate of silver nanoparticles was washed in methanol three times. The resulting pellet was dried in oven at $65^{\circ} \mathrm{C}$ for 24 hours and then collected in tubes for further use.

\subsection{Antimicrobial Analysis}

Biosynthesized silver nanoparticles were tested for antimicrobial activity against isolated oil spot disease causing bacteria. Freshly prepared $100 \mu \mathrm{L}$ of the isolated pathogen was spread on the sterile nutrient agar plates. By using cork-borer a hole was made in the petri plates. Then 100 $\mu \mathrm{L}$ of each suspension of Milli-Q water as a control, silver nanoparticles, silver nitrate as positive control was added into the wells. Plates were incubated at $37^{\circ} \mathrm{C}$ for 24 hours, and then the zone of inhibition was measured in mm (Figs. 3 and 4, Table 4).

\section{Results and Discussion}

\subsection{Colony Characteristics}

The yellow and pale yellow coloured colonies were observed on the YDC agar medium. The morphological characters of the isolate were studied and are as given in Table 1 . This isolate was characterized by the biochemical tests and the causative agent was may belongs to Xanthomonas $s p$.

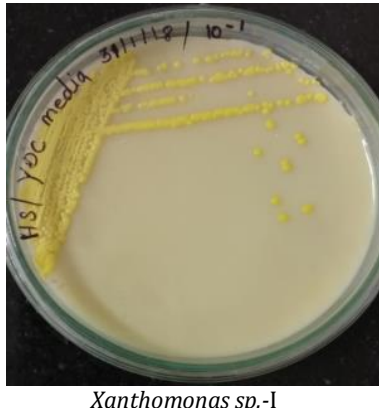

Xanthomonas sp.-I

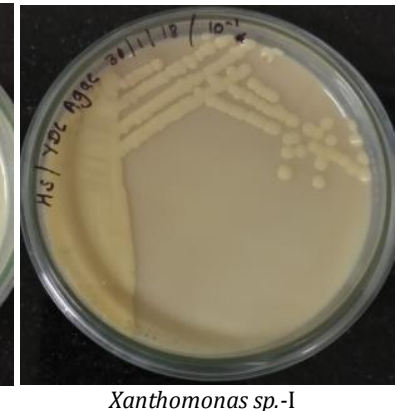

Xanthomonas sp.-I
Fig. 1 Results of isolates on YDC Agar plates

Table 1 Colony characters of isolated pathogen

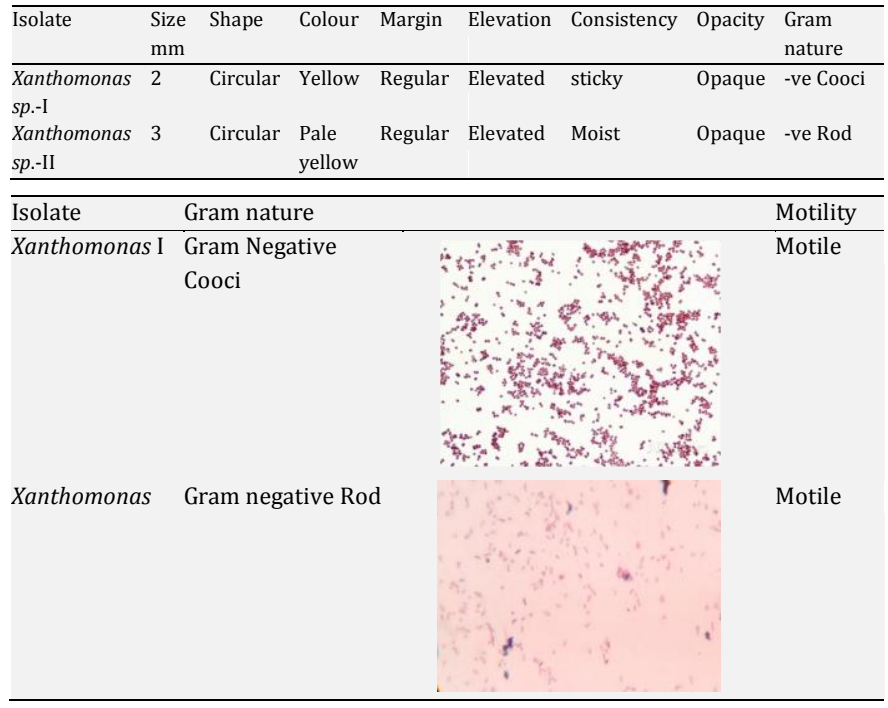

\subsection{Biochemical Characteristics of Isolates}

The biochemical characters of isolate Xanthomonas sp.-I and Xanthomonas sp.-II are given in Table 1. Identification of isolates were done by comparing various colony morphological and biochemical tests according to Bergy's manual.

\begin{tabular}{llll}
\hline Sr.No & Characteristics & Xanthomonas sp.-I & Xanthomonas sp.-II \\
\hline 1 & Methyl Red Test & - & - \\
2 & Voges Proskauer Test & - & - \\
3 & Indole Test & - & - \\
4 & Catalase Test & + & + \\
5 & Oxidase Test & - & - \\
\hline
\end{tabular}

\subsection{Synthesis of Silver Nanoparticles}

As the leaf extracts were added to different concentrations of aqueous silver nitrate solution, the colour of the solution changed from faint light to yellowish brown to reddish brown and finally to colloidal brown indicating AgNP formation. The completion of reaction between leaf extract and $\mathrm{AgNO}_{3}$ was observed. Absorption spectra of AgNPs formed has absorption maxima in the range of 420 to $460 \mathrm{~nm}$ (Fig. 2).

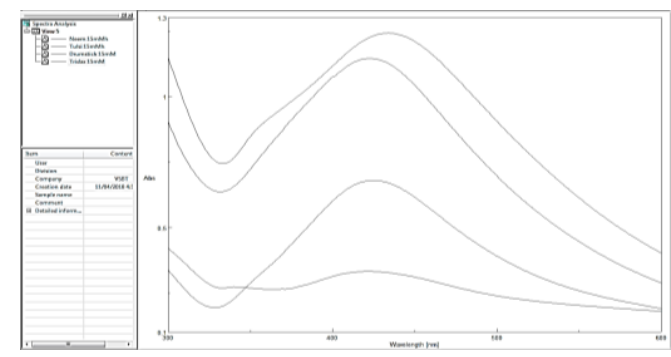

Fig. 2 Spectral analysis of silver nanoparticles

Table 3 Common name of plants used for synthesis of AgNP's, scientific name and their Spectral analysis of extracts was carried to find out $\lambda$-max of nanoparticles. $\lambda$ max for nanoparticles isolated from different plants listed

\begin{tabular}{lll}
\hline $\begin{array}{l}\text { Common Name of Plants used } \\
\text { for synthesis of AgNP's }\end{array}$ & Scientific Name & $\lambda$ - max of AgNP's \\
\hline Neem & Azadirachta indica & $434 \mathrm{~nm}$ \\
Tulsi & Ocimum tenuiflorum & $425 \mathrm{~nm}$ \\
\hline
\end{tabular}

\subsection{Anti-Microbial Activity of Extract}

The antimicrobial activity shows most rapid bioreduction in $5 \mathrm{~mL}$ extract of tulsi and neem, of $15 \mathrm{mM}$ concentration of silver nitrate solution. Results obtained are shown in Table 4 and Figs. 3 and 4. The inhibition zones obtained indicates maximum antibacterial activity of the prepared test sample.

Table 4 Antibacterial activity of plant extract which were treated with $\mathrm{AgNO}_{3}$ and AgNPs against Xanthomonas axonopodis pv. punicae showing zone of inhibition (mm)

\begin{tabular}{lllll}
\hline Organism & \multicolumn{2}{l}{ Xanthomonas sp.- I } & \multicolumn{2}{l}{ Xanthomonas sp.- II } \\
\hline Positive Control $\left.\mathrm{AgNO}_{3}\right)$ & $12 \mathrm{~mm}$ & \multicolumn{3}{l}{$10 \mathrm{~mm}$} \\
\cline { 2 - 5 } Sample & Leaf extract & AgNP's & Leaf extract & AgNP's \\
\cline { 2 - 5 } Tulsi & $8 \mathrm{~mm}$ & $22 \mathrm{~mm}$ & $7 \mathrm{~mm}$ & $17 \mathrm{~mm}$ \\
Neem & $5 \mathrm{~mm}$ & $19 \mathrm{~mm}$ & $5 \mathrm{~mm}$ & $16 \mathrm{~mm}$ \\
\hline
\end{tabular}
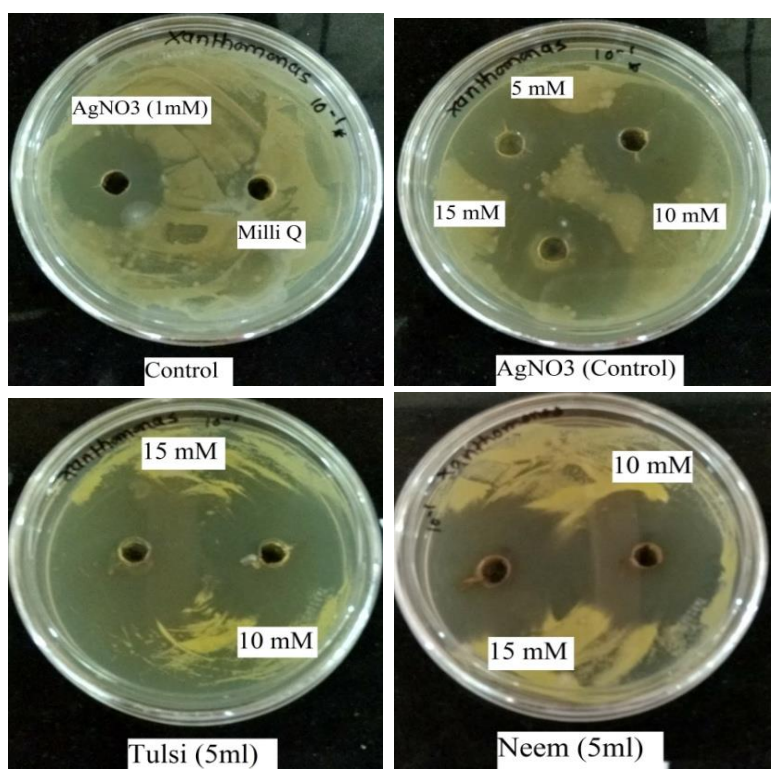

Fig. 3 Results showing the antibacterial activity of control, $\mathrm{AgNO}_{3}$ (control), tulsi, and neem at (10 mM conc.) against Xanthomonas axonopodis pv. punicae 


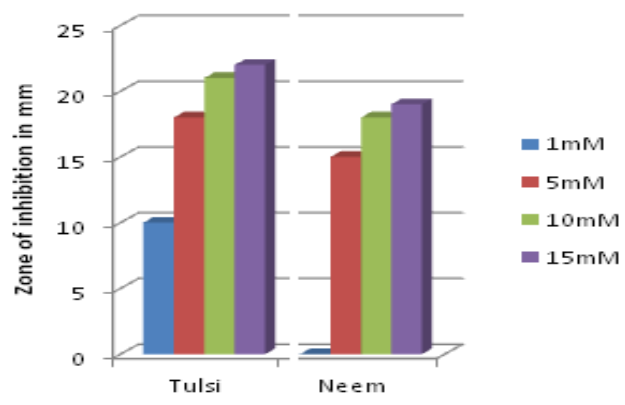

Fig. 4 Antibacterial activity of plant extracts which were treated with $\mathrm{AgNO}_{3}$ and AgNPs against Xanthomonas axonopodis pv. punicae showing zone of inhibition (mm)

\section{Conclusion}

Xanthomonas axonopodis pv. punicae which cause bacterial blight disease to the pomegranate that affects around $80 \%$ of the production. The current scenario, nanotechnology provides a good platform to overcome the problem and resolved it with help of synthesizing silver nanoparticles from leaf extracts of tulsi, and neem at variable concentrations. This study showed that synthesized silver nanoparticles having bactericidal potential and successfully controlled the growth of Xanthomonas axonopodis pv. punicae. Therefore, silver nanoparticles would be used as powerful weapons against Xanthomonas axonopodis pv. punicae even at very lower concentrations.

\section{References}

[1] K.K. Mondal, J. Sharma, Bacterial blight: an emerging threat to pomegranate export, Indian Farming. 59(8) (2009) 22-23.

[2] J. Jurenka, Therapeutic applications of pomegranate (Punica granatum L.) A review, Alt. Med. Rev. 13(2) (2008) 128-144.

[3] A. Caceres, L.M. Giron, S.R. Alvarado, M.F. Torres, Screening of antimicrobial activity of plants popularly used in Guatemala for treatment of dermatomucosal diseases, J. Ethnopharmacol. 20 (1987) 223-237.
[4] A. Saxena, N.K. Vikram, Role of selected Indian plants in management of type 2 diabetes - a review. J. Altern. Compl. Med. 10 (2004) 369-378.

[5] G. Turk, M. Sonmez, M. Aydin, Effects of pomegranate juice consumption on sperm quality, spermatogenic cell density, antioxidant activity, and testosterone level in male rats, Clin. Nutr. 27 (2008) 289-296.

[6] S.A. Naqvi, M.S. Khan, S.B. Vohora, Antibacterial, antifungal, and antihelminthic investigations on Indian medicinal plants, Fitoterapia. 62 (1991) 221-228.

[7] M.V. Dassprakash, R. Arun, S.K. Abraham, K. Premkumar, In vitro and in vivo evaluation of antioxidant and antigenotoxic potential of Punica granatum leaf extract, Pharm Biol. 50(12) (2012) 1523-1530.

[8] C.V. Ambadkar, A.S. Dhawan, V.N. Shinde, Integrated management of bacterial blight disease (oily spot) of pomegranate caused by Xanthomonas axonopodis pv. punicae, Int. J. Plant Sci. 10(1) (2015) 19-23.

[9] R. Lokesh, Erayya, K.M. Kumaranag, N. Chandrashekar, A.N.A. Khan, In vitro efficacy of some antibiotics against bacterial blight of pomegranate caused by Xanthomonas axonopodis pv. punicae, Int. Res. Jour. Biol. Sci. 3(1) (2014) 3135.

[10] R.S. Kumar, M.R. Jahagirdar, S.T. Yenjerappa, H.B. Patil, Epidemiology and management of bacterial blight of Pomegranate caused by Xanthomonas axonopodis pv. punicae, Acta Hort. 818 (2009) 291-296.

[11] D. Juan, Y. Tae-Hoo, Biosynthesis of silver nanoparticles by Variovorax guangxiensis THG-SQL3 and their antimicrobial potential, Mater. Lett. 178 (2016) 75-78.

[12] Z.P. Xu, Q.H. Zeng, G.Q. Lu, A.B. Yu, Inorganic nanoparticles as carriers for efficient cellular delivery, Chem. Eng. Sci. 61 (2006) 1027-1040.

[13] Priya, M. Satapathy, A. Mukhopahayay, P. Das, Leaf extract mediated green synthesis of silver nanoparticles from widely available Indian plants: Synthesis, characterization, antimicrobial property and toxicity analysis, Biores. Bioproc. 3(1) (2014) 1-10.

[14] M. Forough, K. Farhadi, Biological and green synthesis of silver nanoparticles, Turk. J. Eng. Enviorn. Sci. 34 (2010) 281-287.

[15] P. Logeswari, S. Silambarasan, J. Abraham, Ecofriendly synthesis of silver nanoparticles from commercially available plant powders and their antibacterial properties, Sci. Iran. 20 (2013) 1049-1054.

[16] P.V. Kumar, S.V.N. Pammi, P. Kollu, K.V.V. Satyanarayana, U. Shameem, Green synthesis and characterization of silver nanoparticles using Boerhaavia diffusa plant extract and their anti-bacterial activity, Indus. Crops Prod. 52 (2014) 562-566.

[17] O.H. Sangjin, J. Minji, K. Jeonghyo, L. Jaewook, Z. Hongjian, L. Jaebeom, Synthesis of silver nanoparticles using analogous reducibility of phytochemicals, Curr. Appl. Phys. 16 (2016) 738-747.

[18] P. Gong, H. Li, X. He, K. Wang, J. Hu, W. Tan, Preparation and antibacterial activity of $\mathrm{Fe}_{3} \mathrm{O}_{4}$ and $\mathrm{Ag}$ nanoparticles, Nanotechnol. 18 (2007) 604-611. 